\title{
Cyprus: From an Argued Past to a Shared Future
}

\author{
By Jubjana Vila Zeka ${ }^{1}$
}

\begin{abstract}
Most individuals face traumatic events during their lifetime, but when entire groups of people are trapped inside the width and breadth of a horrific atrocity, their experiences can also become a shared or "collective trauma." If an aim of conflict analysis scholars is to contribute to a sustained and peaceful resolution, the psychological and social impact of violence - upon the individual as well as the community - must be broadly examined and synthesized into future strategies and recommendations. The island of Cyprus is home to one of the longest standing and intractable conflicts since the establishment of the United Nations. Its history includes forced occupation, invasion, being traded, and betrayed. There have been military coupes, unilateral decision makers, and aggressive military interventions. Greek Cypriots and Turkish Cypriots have their own historical, fixed, and salient collective trauma. It is a stubborn memory; one that appears and reappears as an old and unhealed wound. The aim of this qualitative study is three-fold: (1) to elucidate the role and effect of opposing Greek Cypriot and Turkish Cypriot trauma narratives upon the peace process; (2) to examine the dialectic exacerbation between the two narratives; and (3) to explore how these narratives have been transmitted to new generations. This research is especially focused on how collective trauma narratives shape perceptions, but at the same time, how they shape social identity, and perceptions of the self. Through a comparison of conflict narratives, this study elaborates on how invalidated or unresolved collective trauma can serve as an insidious source of distrust, enemy imaging, a clash of identities among parties, and how it can also serve to justify each party's actions and reactions. Also, the research aims to explore specific ways the people of Cyprus might be able to move forward from their argued and vehemently opposed understandings of the past, toward a more shared and cohesive future.
\end{abstract}

Keywords: Sustainable Peace, Peaceful Coexistence, Cyprus Conflict, Conflict Narratives, Collective Trauma

\section{Introduction}

Most individuals face traumatic events during their lifetime, but when entire groups of people are trapped inside the width and breadth of an horrific atrocity, their experiences can also become a shared or "collective trauma." As Volkan (1998) notes, a collective trauma may remain in people's memories as communal icons of physical and psychological sufferings. If an aim of conflict analysis scholars is to contribute to a sustained and peaceful resolution, the psychological and social impact of violence - upon the individual as well as the community - must be broadly examined and synthesized into future strategies and recommendations. The Cyprus conflict is an example which needs more work on psychological and social consequences of collective violence, for a peaceful coexistence among conflicting groups

The island of Cyprus is home to one of the longest standing and intractable conflicts since the establishment of the United Nations. Its history includes forced occupation, invasion, being traded, and betrayed. There have been military coupes, unilateral decision makers, and military interventions. Scores of failed, aborted, and broken accords, treaties, or agreements have been attempted by NATO, the United Kingdom, and the United Nations; decades of failed $3^{\text {rd }}$ party interventions have left Cypriots frustrated and hopeless. A study conducted among Greek 
Cypriots voters (Georgiades, 2007) revealed mistrust, ethnocentrism, stereotypes, and suspicion as critical factors in how they voted. Broome (2005), a chief negotiator in previous interventions, also speculates that fear and insecurity remain high because of limited bi-communal experience, the media, and heavily biased historical narratives taught within the distinct and separate educational systems. To illustrate, the trauma narrative for Turkish Cypriots is often linked to the 1960's when Greek Cypriot hardliners blocked their civil rights and inter-communal intimidation and terror emerged. The Greek Cypriots, however, place an emphasis on the "Turkish Invasion" and "forced occupation" since 1974. Both groups have their own historical, fixed, and salient collective trauma. It is a stubborn memory; one that appears and reappears as an old and unhealed wound.

Trauma research for a long time has been focused on individual trauma, but recently the interest for research on collective trauma is rising. In the last decades, the shift from interstate to intrastate conflicts brought the focus to intergroup conflict dynamics. Addressing intergroup social, material and psychological issues came to the agenda and reconciliation emerged as an important topic for discussion. Peaceful coexistence and a shared future for conflicting communities is the aim and collective trauma appeared as an important issue to be addressed. In this article I will work on how collective trauma has shaped the conflict narratives of Greek Cypriots and Turkish Cypriots firstly. Then I will elaborate on how different narratives of the same conflict, shaped by collective traumas, become an obstacle to conflict resolution. Finally, it is my hope to explore the specific ways the people of Cyprus might be able to move forward from their argued and vehemently opposed understandings of the past, toward a more shared and cohesive future.

Firstly, the most important ideas found in collective trauma literature will be presented. I will concentrate on answering questions like what is collective trauma, how it evolves and develops, what are the phases it passes through, what are some of its dynamics and what are some important steps to be taken to move toward collective trauma healing. After giving important knowledge from collective trauma literature, I will present the case of Cyprus conflict and compare and contrast conflict narratives of Greek Cypriots and Turkish Cypriots.

\section{Collective Trauma}

When a traumatic experience is shared by a group of people or an entire society it is defined as "collective trauma". "Collective trauma applies to any society, ethnic group, social category or class which has been exposed to extreme circumstances of traumatization, such as natural disasters, technological catastrophes, and social, political, cultural, gender, ethnic, or religious persecution' (Veerman, 2001, 3). Collective traumas can be either man-made or caused by natural forces (Kellerman, 2007; Apfel \& Simon, 2000; Marsella, Johnson, Watson, \& Gryczynski, 2008). Collective trauma has always been part of the history and memory of the people experiencing shared traumatic events. Some of the main man made collective trauma experiences include: war, genocide, terrorism etc.

At the beginning the word trauma was used to indicate a breaking point of body tissue, but later it started to be used in a metamorphic sense for a negative impact and a psychological breaking point in the lives of people who experienced great misfortune outside the range of ordinary human experience (Jung, 1954; Somasundarama, 2001; Kellerman 2007, 41). Different from individual trauma, which affects the mind and body structure of a person, collective trauma affects the structure of the society. Erikson (1976) defines collective trauma as 'a blow to the basic tissues of social life that damages the bonds attaching people together and impairs the prevailing sense of communality (233).'

Collective trauma develops in a slow and maybe dangerous way into the awareness of the people 
who suffered from a collective traumatic experience (Erikson, 1976, 187).

Collective trauma can sever previous sources of support and the social ties of survivors with each other and with the locale, but those ties and support are very important psychological factors needed when stress is present (Bolin \& Bolton, 1986; Kellerman, 2007). Also collective trauma undermines communality but the emergence of new communities is always possible (Bolin \& Bolton, 1986; Veerman, 2001).

The shared basic values, shared environment and the way the community perceives itself and the world are affected by collective trauma. As a result myths, religious traditions and collective traumatic memories start to appear on the scene. After looking at what is collective trauma and what happens when it appears, let's look how it develops.

\section{Phases of Collective Trauma}

The literature on trauma is in agreement that the immediate period after trauma experience is very crucial and it this is the period when most coping occurs (Brewin, Andrews, Rose, and Kirk, 1999; Shalev, 2002). Coping includes biological, social, emotional, and cognitive processes (Pearlin \& Schooler 1978; Shalev, 1994; Tuval-Maricah et al., 2004, 280). Kellerman (2007), in his book 'Sociodrama and Collective Trauma', mentions about six phases through which collective trauma passes. Those phases include the shock phase, the reactive phase, the coping phase, long term effects, trans-generational transmission of trauma and the universal influence of trauma on the history of humankind (Kellerman, 2007).

The period immediately after traumatic event includes the shock phase and reactive phase. The shock phase means the start of the traumatic event which includes chaos and disorder and people cannot understand what happened (Ehrenreich, 2001; Kellerman 2007). In this phase immediate intervention for basic needs is crucial. In the reactive phase that is directly after the traumatic event, 'the survivors start to react on trying to understand what has happened and the damage, and respond emotionally to the loss and destruction' (Kellerman, 2007). Collective responses can include the fear, inability to understand what happened, avoiding things that remind the event and a wish to be together or alone, according to Kellerman $(2007,46)$. Also it is very important for the survivors to be listened and validated (Foy et al, 2004; Kellerman 2007). According to Volkan (2001) in this stage there is a kind of social regression and evaluation of shared group identity.

Coping phase and long-term phase happen after some time has passed since the traumatic event has happened. Coping phase, which changes from one society to the other, stars a few weeks or months after the traumatic event. In this phase, community deals with the traumatic experience and decide whether to move forward, which means forgetting and denying the experience, or remain stuck in that experience. The long term phase, starts many months or years after the traumatic event. In this phase the buried memories will reappear within individuals and communities, after a period of silence (Wilson, 2002; Kellerman, 2007). Triggering events can be a reason for reappearance.

Last phases appear after a long time has passed since the collective traumatic experience. Transgenerational transmission of trauma starts generations after the event. The collective trauma is transmitted to new generations or people that did not directly suffered the traumatic experience (Volkan et al., 2002). According to Kellerman (2001), the traumatic content not the traumatic event itself is implanted into the conscious and unconscious minds. The last phase of collective trauma is the universal influence of trauma on the history of humankind. A strong relationship among group identity and collective trauma is obvious. Collective trauma becomes which becomes part of collective unconscious and shapes conflict narrative absorbed in collective identity will be told to future generations (Tuval-Mashiach et al. 2004; Kellerman, 2007).

According to Volkan (2008), the people living traumatic events can share five experiences which 
include: shared sense of shame, humiliation and victimization; shared sense of guilt for surviving while others perished; shared (defensive) identification with the oppressor; shared difficulty or even inability to mourn losses; and in the absence of healing shared trans-generational transmission of trauma (Volkan, 2008).

The collective traumatizing political, social and economic conditions worsen identity vulnerability that starts with the individual trauma (Volkan, 2008). When whole communities suffer atrocity, trauma becomes part of the family, of the community and of the society for generations, and the narrative of the community or collective trauma may begin to be told only in the comming generations (Audergon, 2004, 20-21). Similarly Volkan (2008) explains "transgenerational transmission of chosen traumas" as transmitting the unresolved traumatic experiences of the past generations to the new generations. Transmission occurs through telling stories of the trauma and behavior. After transmission it becomes new generations' task to mourn the traumatic experiences. (Volkan, 2008)

\section{Toward Healing}

The collective traumatic experiences shatter the worldview of the people, their livelihood is disrupted and they can lose the motivation for advancement, progress and cooperation for a better future. They cannot trust the world order and people of the other communities anymore; they feel afraid and insecure (Somasundaram, 2001, 3). For example, the changes in community level in the aftermath of mass trauma have included erosion of basic trust, silence, deterioration in social norms, morals and values, and poor leadership (Catani, Schauer \& Neuner, 2008; Commission for Historical Clarification, 1999; Somasundaram, 2001; as cited in Bombay, Matheson \& Anisman, 2009). People who have feelings of victimization consider defensive even violent actions against the others as just, but healing from such psychological wounds of victimization would reduce the need of defensive actions (Bar-Tal, 2003). Reduction in violence will bring reduction in suffer and pain, which will open the possibilities for reconciliation among communities.

Mistrust, hostility and fear are among feelings of enmity that develop among conflicting communities, and peace agreements do not by itself address these feelings. Violence among communities can be stopped by peace agreements, but there always exist a probability for violence reemergence in a post conflict environment (Staub et al., 2005). To have a lasting peace, change in people's attitude toward each other is crucial (Staub et al, 2005). Acknowledging the past atrocities is considered as an important step toward reconciliation and healing of collective trauma, but denying "what really happened" makes healing process even more difficult (Lemarchand \& Niwese, 2007,166; Brounéus, 2003). In social and psychological post-conflict reconstruction is important to take in consideration the radical transformation of people's or community's beliefs systems and codes of conduct. It is important to understand the relationship among individuals and collective memories and its contributing to such radical transformations. According to Lemarchand and Niwese (2007) memory and history go hand in hand. They state that, 'belief systems are in part shaped by history, which in turn is inextricably bound up with the claims of memory' (Lemarchand \&Niwese, 2007, 181; as cited in Hinan, 2010).

'Ethnic amnesia, blind spots and denials of historical evidence isolate the unpleasant truths and enlarge others out of all proportion' (Lemarchand, 2009, 100). Different groups present different memories of the same historical event. Also, the atrocities presented in collective narratives of different groups are used to mobilize entire communities against each other (Lemarchand \&Niwese, 2007). Harmful acts of the past can bring even more harmful acts in the present (Buss, 1966; Goldstein, Davis, \& Herman, 1975).

Working through collective memories of trauma, which shape conflict narrative, is essential and 
more important than revenge, forgiving or forgetting. It will help to bring into focus alternative perceptions of the past events, to show that nothing that happened in the past can be changed, but the meaning of what happened can change and this would open the way to forgiveness and peaceful coexistence.

According to some scholars, like Ricoeur and Hoffman, including in grassroots' agenda reconciliation initiatives based on fostering trust, cooperation and coexistence is very important. Ernest Renan's famous quote state that "getting its history wrong is part of being a nation", but the reality shows this to be at the same time a barrier to the rebirth of a nation, coexistence and reconciliation for a peaceful future. In order to investigate people's perceptions about traumatic events, is important to look at the narratives about traumatic events (Smyth, Hockemeyer, \& Tulloch, 2008; Smyth, True, \& Souto, 2001; as cited in Freitag, Grimm \& Schmidt, 2011).

Living peacefully in a post conflict environment is a crucial and difficult task. The Cyprus conflict is a protracted conflict and a lot of studies are done and initiatives are taken to contribute to this conflict resolution. While a lot of reconciliation initiatives are taken in Cyprus conflict, looking at how the people of this divided island tell the story of their collective traumas is very important. I will give some general information about Cyprus conflict and then present the Greek-Cypriots and Turkish Cypriots Conflict narratives.

\section{The History of Cyprus Conflict}

In 1571 Cyprus became part of the Ottoman Empire. The Island remained under its direct rule until 1871 when it was leased to United Kingdom for administration.

The island was annexed by United Kingdom during the First World War. In 1923 Turkey and Greece, in Lausanne Treaty, agreed that Cyprus belonged to United Kingdom (Müftüler-Bac, 1999).

The Greek Cypriots that supported enosis, meaning the unification of the Island with Greece, started their struggle against British rule in 1925 and continued until the end of the Second World War. They started to organize under a paramilitary organization called "The National Organization for Cypriot Fighters" (EOKA), which started its armed struggle against British rule in 1955 (Müftüler-Bac,1999). On the other side Turkish Cypriots wanted 'Taksim, which means partition of the island or a union of part of the island with 'motherland' Turkey' (Hadjipavlou, 2007, 55). In 1957 Turkish Cypriots, as a response to EOKA, established "Turkish Resistance Organization" (TMT). 1950s witnessed a clash of aims of both communities, which lead to the civil war among Turkish Cypriots and Greek Cypriots and marked the starting point of collective traumas.

London- Zurich Accords, signed by Turkey, Greece and Britain in 1959-1960, ended the 1950s civil war in Cyprus. The Accords reached a compromise 'for the establishment of an independent republic of Cyprus in which both communities would share the public offices, which they would elect representatives through popular vote' (Richmond, 1998, 74-75).

Greece, Turkey and Britain, became guarantors of the domestic regime and Cyprus was announced as an independent country in 1960.

Even though there were frictions among Turkish and Greek Cypriots before, the real Cyprus problem started in 1960s. Led by Makarios Greek Cypriots' decision to modify the constitution against Turkish Cypriots by giving minority status to them and the revival of EOKA activities aiming at enosis triggered the troubles in 1963 (Müftüler-Bac,1999). The island divided into two parts by a line, called the "Green Line". The UN Security Council, with Resolution 186, sent UN Peacekeeping Forces to Cyprus in 1964 and its mandate has been extended every six months since then (Richmond, 1998). During this period Turkey was prevented by international community to intervene in the protection of Turkish Cypriots. 
In July 1974, the Nationalistic Greek junta overthrew Makarios and claimed the annexation of the island to Greece, by violating the London-Zurich Accords (Müftüler-Bac, 1999). Turkish government put a lot of effort for peaceful resolution but didn't take response, and 'Turkey intervened as a guarantor state on 20 July 1974 to protect Turkish Cypriots and prevent annexation of Island to Greece' (Çini, 2002, 29). In 1983 the Turkish Cypriot leadership, based in the principle of self determination declared their independence and established the Turkish Republic of Northern Cyprus (TRNC). TRNC is recognized only by Turkey, and is declared as legally invalid by UN Security Council.

Cyprus issue has gain importance in United Nations agenda, but despite lots of talks and negotiations still no mutually acceptable agreement is reached. In 2004 Annan Plan was an important initiative taken by UN Secretary General, which was put to a referendum but no successful result came out, because ' $76 \%$ of Greek Cypriots who voted said 'No' and 67\% of Turkish Cypriots who voted said 'Yes' to the plan (Heraclides, 2011, 124). Republic of Cyprus became European Union member on 1 May 2004, which is considered as a new turning point in the recent history of Cyprus. Another UN initiative has been a meeting between the leaders of the two communities in July 2006, where they both agreed to the establishment of technical committees with the purpose of discussing day-to-day issues and core issues. In June 2012 a new resolution is expected to come out from UN Security Council concerning the Cyprus issue.

As previously mentioned, Cyprus conflict is considered as a protracted conflict and the role of history and the shared collective trauma memories, as barriers to a political settlement in Cyprus, are important topics of discussion. The conflict in Cyprus has brought a lot of pain and suffering from the violence for both communities. Each community has its own shared traumatic memory of these sufferings and pain, which has an important impact on the structure of the conflict and relations between two ethnic communities.

\section{Methodology}

This research is based on explaining and comparing conflict narratives of both Greek Cypriots and Turkish Cypriots. The main themes and events that appear in each community's conflict narrative, based on collective trauma, will be included in analysis. Narratives are stories of the conflict told from each community's perspective. Secondary sources will be used for the purpose of this research and the main sources come from J-Store, EBSCO, Google Scholar databases and Sabanci University's Information Center. Two books and forty articles are used to conduct this research.

Different narratives of the same conflict and the transmission of collective trauma to new generations, through these narratives, are important obstacles in conflict resolution. This idea encouraged me work and explore what should be done to create a common narrative, which will be very helpful in conflict resolution and peaceful coexistence of communities. Narrative analysis is very helpful in marking the common ground for different communities telling their collective traumas. The main themes that appear in conflict narratives of Turkish Cypriots and Greek Cypriots include: fear, identity-threat, lack of trust, 'we vs. others' or 'in group vs. out group', victimization, etc.

A lot of work is done concerning the policies that should be followed to resolve the Cyprus conflict. Except the track one initiatives, a lot of track two initiatives have been taken in this conflict. The main focus has been to bring people together and work with perceptions, stereotypes, prejudices they have on each other, but the impact that history and collective trauma has in shaping their cognitive and psychological world is not taken into consideration enough. Working with the psychological reasons that shaped the perceptions of the people from different communities about each other is very crucial. Collective traumas include very important events 
that shape people's thinking about the other group in the conflict. Dealing with this collective traumas and its impact on shaping different collective narratives is important in helping to create a shared history. A shared history combined with mutual accepted conflict resolution and the people's work on reducing stereotypes, prejudices and other psychological elements is very essential in creating a shared peaceful future.

I will compare their narratives based on the main themes that appear in both narratives, which will lead me to the discussion about how to deal with these opposing collective trauma narratives and how important is creation of a common conflict narrative for both communities to move forward to a peaceful coexistence.

\section{Conflict Narrative of Greek Cypriots and Turkish Cypriots}

The first time that Greek and Turkish Cypriots started to live together date back to $15^{\text {th }}$ century. They have passed through a difficult history and an unresolved conflict but each of the communities has its own narrative of history and conflict. The main traumatic events in Cyprus issue include 1963-1974 period for Turkish Cypriots and 1974 for Greek Cypriots.

The conquest of the Island by the Ottoman Empire is presented differently in Greek and Turkish Cypriots' narratives. Greek Cypriots' narrative mentions the conquest of the island as a catastrophe because it marked 'the end of the glorious Byzantine Empire's civilization, which is seen by the Greek Cypriots as their own cultural background' (Brouwer, 2009, 23). Greek Cypriots emphasize the idea of the island as a pure Hellenic island that should be united with Greece or enosis (Anastasiou, 2002). They claim that both communities have peacefully coexisted during this period, but Turkish Cypriots were more privileged because of their religion. On the other hand, in Turkish Cypriots' narrative the conquest of the Cyprus by Ottoman Empire is a great victory, because it 'serves as the beginning of Turkish-Cypriots history in Island and is a powerful event to strengthen the Turkish-Cypriot historical claim on Cyprus' (Brouwer, 2009, 23). They claim that during the Ottoman Empire's rule both communities have lived in peace with each other, and that Greek Cypriots had all their rights.

Turkish Cypriots and Greek Cypriots emphasize different reasons that pushed toward interethnic conflict. The narrative of Greek Cypriots for 1950s is mainly based on their struggle for independence from British rule, and enosis of the Island with Greece. Their struggle was led by EOKA, an organization established to fight for independence and unification of the island with Greece. Their struggle for independence from United Kingdom lasted until 1960 when Republic of Cyprus was claimed (Papadakis, 2008). According to Greek Cypriots, Turkish Cypriots wanted Taksim or partition of the Island and during Greek Cypriots struggle for independence Turkish Cypriots aligned with the British by betraying Greek Cypriots. 'Hellenism was threatened and that is what the Greek-Cypriot nationalists were fighting for, from the 1950's onwards' (Brouwer, 2009, 25). Greek Cypriots' narrative mentions the establishment of TMT, in 1958 against EOKA, as the main reason for the start of interethnic violence among Greek Cypriots and Turkish Cypriots for the first time. On the other side, in Turkish Cypriots narrative, the establishment of EOKA is seen as the key event pushing to interethnic conflict. EOKA establishment is the starting point of Turkish Cypriots conflict narrative because the activities of EOKA were directed to Turkish Cypriots too, since they were considered as a threat to enosis. According to Turkish Cypriots the activities of EOKA lead to 1958 interethnic violence. As a response to EOKA's activity Turkish Cypriots felt the need to defend and established TMT. The aim of TMT was to defend from the acts of EOKA and nothing else, according to Turkish Cypriots.

While the collective trauma of Turkish Cypriots is mainly focused on the period 1963-1974, Greek Cypriots' narrative almost ignore this period's events. The independent Cyprus did not satisfied the enosis aim of Greek Cypriots, because they were the majority population on the 
island and they thought they deserved more rights and this led to the constitutional changes in 1963. The 1963-1974 is not an important part in Greek Cypriots' narrative. They consider it as a period with no atrocities between the communities. Only some Greek Cypriots from the left wing accept that violence toward Turkish Cypriots was used in this period (Brouwer, 2009). On the contrary, the conflict narrative for Turkish Cypriots is mainly focused on 1963-1974 period, which is the period on which their main collective trauma memory is based. These years include massive suffering, distress and pain because of the inter-communal violence, which makes impossible for Turkish-Cypriots and Greek Cypriots to live together. This period forms the central part of the narrative and summarizes the whole history of Cyprus for Turkish Cypriots (Brouwer, 2009). 1974 Turkish military intervention and Turkish Cypriots' claim for independence, is encouraged by these traumatic violent years. 'Greek-Cypriots are portrayed as the eternal enemy, which spreads distress and suffering', in Turkish Cypriots narrative of this period (Brouwer, 2009, 26). They remember the violent and bloody clashes with Greek troops and Greek Cypriots and human loss. According to Volkan, the missing people (483 T/Cs over 32 G/Cs in 1964), people's feeling of living under continual pressure and blockade are important elements of Turkish Cypriots collective memory. Turkish Cypriots emphasize their memory of fear and insecurity. Some of them even left their homes to find more secure places to live. Till 1967 they lived under such circumstances, almost in isolation with no contacts with Greek Cypriots. Also economic conditions were difficult for them, because of the trade embargo. After 1967, stability increased and many Turkish Cypriots could return back to their homes. Returning to their homes became traumatic for Turkish Cypriots, when they saw part of their past lives destroyed and this became a strong reason for them to lose their desire for return.

Both Turkish Cypriots and Greek Cypriots highlight the 1974 events, but they emphasize different aspects of it. Conflict narrative for Greek Cypriots and their collective trauma has its origin back to 1974 events which include the Greek coup d'état and the Turkish invasion (Anastasiou, 2002). While they do not pay enough attention to the coup, at the center of Greek Cypriots narrative lies 1974 Turkish military invasion (Brouwer, 2009). In Greek Cypriot's narrative, this event is referred to as "The Catastrophe" which brought misery, injustice and illegal occupation to Cyprus and the atrocities committed by the barbarous Turks on Greek-Cypriots outnumber all the atrocities committed on Turkish-Cypriots in numbers, severity, and magnitude (Brouwer, 2009). This period lies at the heart of Greek Cypriots collective trauma narrative. 'Turkish offensive divided the island; Greek Cypriots fled en masse to the south and Turkish Cypriots subsequently moved to the north. Greek Cypriots had high human cost in terms of people killed, missing, and displaced and the number of displaced people amounted to almost one-third of all Greek Cypriots' (Papadakis, 2008). Material costs for Greek Cypriots increased with their property loss as a result of displacement. Also after the 1974 Turkish military invasion settlers were brought from Turkey to live in the Island, and they were settled in the properties of the displaced Greek Cypriots.

1974 junta coup is an important event in Turkish Cypriots narrative because they faced the real threat to their existence. According to Turkish Cypriots the 1974 junta coup was supported by all Greek Cypriots population, which justifies military invasion of Turkish army to protect Turkish Cypriots. Turkish Cypriots were living under the fear of extinction until the Turkish army arrived, which made Turkish Cypriots to feel secure, free and tranquil for the first time. According to Turkish Cypriots, Turkey used its right as a guarantor state to protect Turkish Cypriots, and there is nothing wrong in its intervention. Turkish Cypriots would not feel secure without Turkish troops there.

In Turkish Cypriots narrative 'the immense and widespread suffering Turkish military intervention ensued to Greek-Cypriots is omitted completely. Only the atrocities committed against the Turkish-Cypriots during the 1960's and after the Coup of 1974, are extensively 
accounted and continuously mentioned' (Brouwer, 2009, 27). This is similar with the situation of Greek Cypriots' narrative of 1963-1974.

The events of 1974 ended the narratives and collective trauma experiences for both communities but for different reasons. For Turkish Cypriots their narrative ends with the intervention of Turkish Military forces and declaration of independence of Northern Cyprus Turkish Republic in 1983, which is a sign of their right for self determination. While for Turkish Cypriots 1974 brought a new beginning, with a new state and an end to atrocities, for Greek Cypriots it was violent and disastrous end to 'their' independent nation with one third of the land occupied by Turkish military troops. After 1974 events, the need to reunite the island made Greek Cypriots to reconsider their aims by encouraging the idea of living in peace with the other ethnic group, referring to their past peaceful coexistence. Still, the memories of different collective traumas that communities narrate are important obstacles in solving the conflict and creating a shared future.

\section{Discussion}

After comparing the narratives, based on collective traumas of Turkish Cypriots and Greek Cypriots, is the time to discuss how to deal with these narratives in order to move forward to shared narrative and a peaceful coexistence of the people in the island.

The initiatives in Cyprus conflict are mainly focused on reconciliation, but starting directly with reconciliation may not be efficient in a protracted conflict. 'Reconciliation simply means coexistence or it can mean dialogue, remorse, apology, forgiveness and healing. Also it means reconstruction of the community, neighborly relationships, families, etc. which were broken due to pain, distrust and fear' (Anderlini, S. N., Cornaway, C. P. \& Kays, L., 2004, 2-3). Reconciliation is an important step, but not the first step directly after a violent conflict. It is not very realistic to expect from people who have suffered from collective violence to leave everything behind, and to move forward to live in peace with the opponent like nothing bad has happened. Even though both Turkish Cypriots and Greek Cypriots want the conflict to come to an end, still they are not ready to bury the past because it is part of their identity and their collective traumas are bounded to this past. We cannot expect Greek Cypriots to forget 1974 events and Turkish Cypriots to forget 1963-1974 events and live peacefully together easily. So, it is important to develop some other steps before reaching to reconciliation among conflicting groups.

Firstly it is very important for each community, Turkish Cypriots and Greek Cypriots, to freely tell their conflict narratives based on their collective trauma and to listen each other's narrative at the same time. 'The survivors did not only need to survive so that they could tell their stories; they also needed to tell their stories in order to survive. There is, in each survivor, an imperative need to tell and thus to come to know one's story. One has to know one's buried truth in order to be able to survive one's life.' (Laub, 1995, 63). Turkish Cypriots need to listen what happened in 1974, according to Greek Cypriots perspective. They to understand what this event brought to Greek Cypriots, why and how they suffered, and why they do not want Turkish troops in the island. On the other side, Greek Cypriots should listen to Turkish Cypriots perspective concerning the events of the same year. They should listen to why they consider Turkish military intervention as right and want Turkish troops to remain there. Greek Cypriots should also listen to what happened in 1963-1974 to Turkish Cypriots, how they suffered and what were the consequences of Greek Cypriots activities in this period. They should understand why in their own narrative this period is not mentioned enough. Turkish Cypriots also should listen why 19631974 is not an important period in Greek Cypriots narrative, what happened in this period according to Greek Cypriots. So, they should listen to each other's narratives and maybe empathize with each other. Listening means to hear with the purpose of understanding what the others are telling. Listening to each other's narrative would help them understand each other's 
collective traumas, feelings of victimization, fear, distrust etc. The problem with Cyprus conflict is that even though each community is telling its narrative, the other community does not have the will to listen. Each of them want to be listened, but is not willing to listen, but one community cannot expect to be listened when it's not willing to listen the other community. This process should happen simultaneously, and is possible to happen if both communities are willing to solve the conflict and focus on a peaceful future.

The second step, which is the most important step in Cyprus conflict and in most of the conflicts, is acknowledgment by the communities of each other's collective traumas. If communities remain divided with divided narratives of the conflict, it means that they are stuck and resolution of the conflict is not possible. They should acknowledge each other's collective traumas, sufferings, fear, and victimization feelings. Acknowledging the atrocities of the past does not mean that you accept the conflict narrative of the other community as the only narrative or that their narrative is better than yours. Acknowledgment means that you accept that there exists another truth, in addition to your own truth. Acknowledging Turkish Cypriots narrative of what happened during 1963-1974; means to accept that during that period Turkish Cypriots have suffered as they claim. Also, if Turkish Cypriots acknowledge that 1974 military intervention of Turkey in the island brought threat and fear to Greek Cypriots, it means that they recognize the threat and fear that Greek Cypriots feel. Acknowledgment does not mean that one's narrative is wrong and the other's narrative is right, but on the contrary it means that both narratives are accepted by both communities. Acknowledgment is very essential for the parties to understand each other's perception of the conflict, collective traumas, behaviors, feelings and sufferings. At the same time it can help communities to find common grounds, and move toward a shared history for a shared future.

After acknowledgment is the turn for reconciliation initiatives to develop. These initiatives are adopted a lot in Cyprus conflict, so I will not go into details on reconciliation initiatives. I want to emphasize that now in Cyprus conflict, is not the right moment to deal directly with reconciliation initiatives and that these initiatives would be successful if they are employed after the acknowledgement step. We cannot expect the reconciliation of the communities who live separately, and have not acknowledged each other's collective memories and traumas. Moving directly to reconciliation cannot help in a peaceful conflict resolution, but reconciliation after acknowledgment of past atrocities can.

Acknowledgment and reconciliation would encourage both communities to combine their collective trauma memories and create a shared collective trauma. They would accept that bad things happened in the past to both communities, but this does not mean that it would happen in the future. For example a combined collective trauma would include both the collective trauma of Turkish Cypriots in 1963-1974 and the collective trauma of Greek Cypriots in 1974. The people of the island would be aware of both communities' sufferings, and will understand that in the past both of them have been victims and perpetrators at the same time. Empathizing with each other would help them to forgive and heal, and at the same time to understand that the time to find a mutual beneficial conflict resolution has come.

Transgenerational transmission of collective trauma is a big obstacle in conflict resolution, but transmission of a shared collective trauma would not be an obstacle. Turkish Cypriots and Greek Cypriots both continue to transmit to new generations their different collective trauma memories and these memories can cause new generations to feel the fear and threat from each other. On the contrary if shared collective trauma memories would be transmitted to new generations, it would help them to understand that the past has been cruel for both communities but the future is in their hands. They would understand that they are the people of the same island; they have had good coexistence periods in the past which would encourage them to think that they could mourn and live peacefully with each other in the future. History is a tool through which these collective 
traumas are transmitted, so creating a shared history or collective narrative from the combination of collective traumas would be very essential. Moving from different collective traumas and different conflict narratives to a shared conflict narrative is a healing process at the same time. This healing process would have great influence in creating a shared peaceful future among communities.

A shared conflict narrative, combined with mutually accepted conflict resolution outcomes concerning material, social and political issues, would be a big development in leaving Turkish Cypriots and Greek Cypriots to leave peacefully in their own Island.

The cooperation of leaders, scholars and media is important too. Leaders should not use these collective trauma events to manipulate and mobilize the people inside their communities, but they should help them to create a shared history. Scholars should work on emphasizing the importance of a shared history, and practitioners should work on helping the people of the communities to move from their different collective trauma memories to a shared future. Also the role of media is very important since it one of the tools that can reach both communities simultaneously, and one of the best tools to channel the communication among communities.

\section{Conclusion}

Collective trauma recently is a topic which needs a lot of attention, especially in protracted conflicts whose resolution is difficult. Cyprus conflict is one of the conflicts in which the role of collective trauma is important. Different conflict narratives which are shaped by different collective traumas can be an important obstacle for conflict resolution. While Turkish Cypriots conflict narrative is mainly based on collective trauma of 1963-1974 periods, Greek Cypriots conflict narrative focuses on 1974 Turkish military intervention or invasion as they claim. Both communities have different collective traumas and different conflict narratives. A lot of reconciliation initiatives are taken in Cyprus, but conflict is not resolved. In this research I tried to emphasize the need for gradual movement from telling the conflict narratives by both communities and acknowledgement of the collective traumas, to reconciliation and a shared history and future. I want to highlight the importance and the need of telling conflict narratives by both communities and acknowledging each other's collective trauma, as two primary steps but absent in Cyprus conflict resolution efforts. It is very crucial to acknowledge the past atrocities in order to bring parties together to reconcile, to focus on creating a common narrative to be transmitted to new generations in order to encourage the peace among communities.

In Cyprus conflict there is not acknowledgment of the collective traumas among communities. Each of the communities has its own story of the conflict and does not recognize the conflict narrative of the other community. Recognizing the atrocities of the past would help both communities to feel empathized and validated, concerning their sufferings and feelings. Acknowledgment of collective traumas for both sides would be a big step toward healing. It does not mean that one narrative will win over the other, but will open the way to the combination Turkish Cypriots and Greek Cypriots narratives as a hope for creating a shared history and moving to a peaceful coexistence in the future. My main emphasis is on the importance of acknowledging the atrocities of the past as a crucial step for a peaceful future in Cyprus. Acknowledging past traumas will open the way to move from a divided past to a shared future.

\section{References}

Anastasiou, H. (2002), Communication Across Conflict Lines: The Case of Ethnically Divided Cyprus, Journal of Peace Research, 39 (5): 581-596.

Anderlini, S. N., Cornaway, C. P. \& Kays, L. (2004), Trasnsitional Justice and Reconciliation. Justice, Government and Civil Society. 
Apfel, R. J., \& Simon, B. (2000), Mitigating discontents with children in war: An ongoing psychoanalytic inquiry, 102-130. In A. C. G. M. Robben \& M. M. Suarez-Orozco (Eds.), Cultures under Siege: Collective Violence and Trauma New York: Cambridge University Press.

Audergon, A. (2004), Collective Trauma: The Nightmare of History, Psychotherapy and Politics International, 2(1): 16-31, London: Whurr Publishers LTD.

Bar-Tal, D. (2003). Memory of Physical Violence: Its Contribution to the Culture of Violence. In Cairns, E. \& Roe, M. D. (eds), The Role of Memory in Ethnic Conflict. (77-93). Houndsmills, England: Palgrave Macmillian.

Bolin, R., \& Bolton, P. (1986), Race, Religion and Ethnicity in Disaster Recovery, Program on Environment and Behavior, Monograph, no: 34. University of Colorado: Boluder, CO.

Bombay, A., Matheson, K., \& Anisman, H. (2009), Intergenerational Trauma: Convergence of Multiple Processes among First Nations peoples in Canada, Journal de la Santé Autochtone, National Aboriginal Health Organization.

Brewin C. R., Andrews, A.., Rose, S., \& Kirk, M. (1989), Acute Stress Disorder and Posttraumatic Stress Disorder in Victims of Violent Crime. American Journal of Psychiatry, 156, 360-366.

Brounéus, K. (2003), Reconciliation-Theory and Practice for Development Cooperation, The Department for Cooperation with Non-Governmental Organizations and Humanitarian Assistance, SIDA, Edita Sverige AB.

Broome, B. (2005), Building bridges across the Green Line. Nicosia: United Nations Development Programme.

Brouwer, M. (2009), Different Images of the Same Past, The Institutionalization of Historical Narratives in Cyprus as Reflections of Turkish-Cypriot and Greek-Cypriot Nationalisms, Utrecht University.

Buss, A., H. (1966), Instrumentality of aggression, feedback and frustration as determinants of physical aggression, Journal of Personality and Social Psychology, 3, 153-162.

Catani, C., Schauer, E., \& Neuner, F., (2008), Beyond Individual War Trauma: Domestic Violence against Children in Afghanistan and Sri Lanka, J Marital Fam Ther, 34(2):165-176.

Çini. N. (2002), Getting to the Table Process: Underlying Conditions of the Turkish-Greek Cypriot Rapprochement of December 2001, Sabanci University Thesis Database.

David W. Foy, William S. Unger, Melissa S. Wattenberg, (2004), Group Interventions for Treatment of Psychological Trauma, Module 4: An Overview of Evidence-Based Group Approaches to Trauma with Adults, American Group Psychotherapy Association. http://www.agpa.org/pubs/4adults-ebt.pdf

Erikson, K. T. (1976). Everything in its Path.: Destruction of Community in the Buffalo Creek Flood. New York: Simon and Schuster

Freitag,S., Grimm,A.,\& Schmidt, S. (2011), Talking about Traumatic Events: A cross-cultural investigation, Europe's Journal of Psychology, 7(1): 40-61.

Georgiades, S. (2007), Public attitudes towards peace: The Greek-Cypriot position, Journal of Peace Research, 44(5): 573-586.

Goldstein, J. H., Davis, R. W., \& Herman, D. (1975), Escalation of Aggression: Experimental Studies, Journal of Personality and Social Psychology, 31, 162-170.

Gordon L. Wilson (2002), Dealing with Trauma. Some guidelines for clergy and pastoral workers involved in understanding and caring for people with traumatic experiences, Handbook, Retrieved on April 20, 2015 from http://www.methodist.org.uk/downloads/pc traumaart0105.pdf

Hadjipavlou, M. (2007), Multiple Stories: The Crossings as Part of Citizens' Reconciliation Efforts in Cyprus? Innovation, 20(1): 53-73.

Heraclides, A. (2011), The Cyprus Gordian Knot: An Intractable Ethnic Conflict, Nationalism and Ethnic Politics, 17, 117-139, Taylor \& Francis Group.

John H. Ehrenreich (2001), Coping with Disasters: A Guidebook to Psychosocial Intervention. Retrieved on April 17, 2015 from http://hss.state.ak.us/dbh/resources/initiatives/dp/Coping\%20With\%20Disaster.pdf

Jung, C. G. (1934-1954), The Archetypes and the Collective Unconscious, (1981 2nd ed. Collected Works Vol.9 Part 1), Princeton, N.J.: Bollingen

Kellerman, P. F. (2007), Socio-drama and Collective Trauma, London: Jessica Kingsley Publishers, 33-50.

Laub, D. (1995), Truth and Testimony: The Process and the Struggle, Trauma Explorations in Memory. ed. Cathy Caruth. Baltimore: Johns Hopkins University Press. 61-75. 
Lemarchand, R. \& Niwese, M. (2007) 'Mass Murder, The Politics of Memory and Post-Genocide Reconstruction: The Cases of Rwanda and Burundi.' After Mass Crime: Rebuilding States and Communities Poulingy, Chesterman and Schnabel (eds). United Nations University Press, 165-189

Lemarchand, R. (2009), Politics of Memory (99-109) in The Dynamics of Violence in Africa, Philadelphia: University of Pennsylvania Press.

Marsella, A. J., Johnson, J. L., Watson, P., \& Gryczynski, J. (2008), Essential Concepts and foundations. In Marsella, A. J., Johnson, J. L., Watson, P., \& Gryczynski, J. (eds), Ethno-cultural Perspectives on Disaster and Trauma: Foundations, Issues and Applications, New York: Springer, 3-14.

Müftüler-Bac, M. (1999), The Cyprus Debacle: What the Future Holds. Futures, 31: 559-575, Elsevier Science Ltd.

Papadakis, Y. (2008), History Education in Divided Cyprus: A Comparison of Greek Cypriot and Turkish Cypriot Schoolbooks on the "History of Cyprus". PRIO Report 2, Oslo.

Pearlin, L.I, and Schooler, C. (1978), The Structure of Coping, Journal of Health and Social Behavior, 22, 337- 356.

Richmond, P. O. (1998), Mediating In Cyprus: The Cypriot Communities and the United Nations, London: Frank Cass Publishers.

Tuval-Mashiach, R., Freedman, S., Bargai, N., Boker, R., Hadar, H., and Shalev, A. Y., (2004), Coping with Trauma: Narrative and Cognitive Perspectives, Psychiatry, 67(3). Retrieved on April 20, 2015 from http://terror-medicine.org/publications files/Trauma $\% 20$ narrative.pdf

Shalev, A.Y. (1994), Multidimensional Approach to the Posttraumatic Stress Disorder. Part I: Theory and Research, Sihot, Israel Journal of Psychotherapy, 8(2): 85-104.

Shalev, A.Y. (2002), Acute stress reactions in adults, Biological Psychiatry, 51(7): 532-543.

Somasundaram. D. (2001), Collective Trauma in Sri Lanka, Intl. J. of Mental Health, Psychosocial Work \& Counseling in Areas of Armed Conflict, 1 (1).

Staub, E. et al. (2005), Healing, Reconciliation, Forgiving and the Prevention of Violence after Genocide or Mass Killing: An Intervention and its Experimental Evaluation in Rwanda, Journal of Social and Clinical Psychology, 24(3): 297-334.

Hinan, T. (2010), To Remember, or To Forget? Collective Memory and Reconciliation in Guatemala and Rwanda, Totem: The University of Western Ontario, Journal of Anthropology, 18(1-1), Berkley Electronic Press. Retrieved on April 15, 2015 from http:/ ir.lib.uwo.ca $/$ cgi/viewcontent.cgi?article $=1195 \&$ context $=$ totem

Veerman, A. L. \& Ganzevoort, R. R. (2001), Communities Coping with Collective Trauma, IAPR Conference Paper, Soesterberg, The Netherlands.

Volkan, V. (1997), Bloodlines. From ethnic pride to ethnic terrorism, New York: Farrar, Straus, \& Giroux.

Volkan, V. (2002), Varieties of Transgenerational Transmission, pp. 27-38. and History-related Unconscious Fantasies in: Volkan, V., Ast G., and Greer. The Third Reich in the Unconscious, NY: BurnerRoutledge.

Volkan, V. (2002), Different Cases, Different Approaches, In: The Third Reich in the Unconscious, Brunner Routledge, 173-192

Volkan. N. (2008), Trauma, Identity and Search for a Solution in Cyprus, Insight Turkey, 10 (4): 95-110. 
